\title{
Expression pattern of the GRAS gene family during somatic embryogenesis in pine
}

\author{
Inmaculada Hernández ${ }^{*}$, Elena Carneros ${ }^{1}$, Alberto Pizarro ${ }^{1}$, Dolores Abarca², Carmen Díaz-Sala ${ }^{2}$ \\ From IUFRO Tree Biotechnology Conference 2011: From Genomes to Integration and Delivery \\ Arraial d Ajuda, Bahia, Brazil. 26 June - 2 July 2011
}

The GRAS protein family of putative transcription factors, which includes SHORT-ROOT (SHR), SCARECROW (SCR) and SCARECROW-LIKE (SCL) proteins, is involved in root development in Arabidopsisthaliana and other plant species [1]. In forest species, genes with homology to the $A$. thalianaSCR gene have been involved in the induction of somatic embryogenesis in Picea glauca (Moench) Voss [2] and Pinus taeda L. [3] as well as in the development of radial patterning of roots in Pinus sylvestris L. [4]. Schrader et al[5] also reported the expression of genes with homology to the A. thalianaSHR gene in cambial region of Populus tremula $x$ tremuloides. Increased levels of mRNA of Pinus radiata SHR (PrSHR), Pinus radiata SCARECROWLIKE1 (PrSCL1) and Castanea sativaSCARECROWLIKE1 (CSSCL1) have been associated with the early stages of adventitious root induction in Pinus radiata D. Don and Castanea sativa Mill., respectively [6-9].

In addition to PrSHR and PrSCL1, we have identified 13 new GRAS genes belonging to the different GRAS clades in the pine genome. The objective of this work is the analysis of the spatiotemporal expression patterns of the pine GRAS gene family during somatic embryogenesis in Pinus radiata D. Don. Somatic embryogenesis has become the first biotechnology showing great potential for mass propagation of conifers for application in forestry, allowing the implementation of multivarietal forestry (MVF) [10,11]. Despite major advances in clonal regeneration by somatic embryogenesis or organogenesis, many forestry species are recalcitrant [12]. More knowledge of the regeneration process regulation is necessary to improve the capacity of vegetative regeneration.

\footnotetext{
* Correspondence: inmaculada.hernandez@uah.es

'Department of Plant Biology, University of Alcalá, Alcalá de Henares, Madrid, 28871, Spain

Full list of author information is available at the end of the article
}

The expression pattern of the genes was analyzed by qRT-PCR following the methodology described by Sánchez et al[6] and Solé et al[7]. For expression analysis, total RNA was extracted from four stages of the somatic embryogenic process: proliferative tissue after 7 and 14 days from the last transference to proliferation medium, somatic embryos at the beginning of differentiation and cotyledonary somatic embryos.

In general, the transcripts of the pine GRAS genes accumulated at the highest levels in cotyledonary somatic embryos. In addition, the transcript levels of PrSCR, PrSHR, PrSCL1, PrSCL6, PrSCL8, PrSCL11 andPrSCL12 showed an increase in somatic embryos at the beginning of differentiation. No differences in PrSCL10 transcript levels were found between the four stages analyzed. Transcript levels of PrSCL16 were undetectable at all stages. In situ hybridization for spatial expression analysis will confirm differential expression domains.

This work has been funded by the Spanish Ministry of Science and Innovation (AGL-2008-05105-C02-01/FOR). Embryogenic lines were provided by C. Walter (Scion).

\section{Author details \\ ${ }^{1}$ Department of Plant Biology, University of Alcalá, Alcalá de Henares, Madrid, 28871, Spain. ${ }^{2}$ Department of Plant Biology, Universtiy of Alcalá, Alcalá de Henares, Madrid, 28871, Spain.}

Published: 13 September 2011

\section{References}

1. Bolle C: The role of GRAS proteins in plant signal transduction and development. Planta 2004, 218:683-692

2. Stasolla C, van Zyl L, Egertsdotter U, Craig D, Liu W, Sederoff RR: The effects of polyethylene glycol on gene expression of developing white spruce somatic embryos. Plant Physiol 2003, 131:49-60.

3. Cairney J, Zheng L, Cowels A, Hsiao J, Zismann V, et al: Expressed sequence tags from loblolly pine embryos reveal similarities with angiosperm embryogenesis. Plant Mol Biol 2006, 62:485-501.

4. Laajanen K, Vuorinen I, Salo V, Juuti J, Raudaskoski M: Cloning of Pinus sylvestris SCARECROW gene and its expression pattern in the pine root
C Biomed Central

C 2011 Hernández et al; licensee BioMed Central Ltd. This is an open access article distributed under the terms of the Creative Commons Attribution License (http://creativecommons.org/licenses/by/2.0), which permits unrestricted use, distribution, and reproduction in any medium, provided the original work is properly cited. 
system, mycorrhiza and NPA-treated short roots. New Phytol 2007,

175:230-243.

5. Schrader J, Nilsson J, Mellerowicz E, Berglund A, Nilsson P, Hertzberg M, Sandberg G: A high-resolution transcript profile across the wood-forming meristem of poplar identifies potential regulators of cambial stem cell identity. Plant Cell 2004, 16:2278-2292.

6. Sánchez C, Vielba JM, Ferro E, Covelo G, Solé A, Abarca D, de Mier BS, DíazSala C: Two SCARECROW-LIKE genes are induced in response to exogenous auxin in rooting-competent cuttings of distantly related forest species. Tree Physiol 2007, 27:1459-1470.

7. Solé A, Sánchez C, Vielba JM, Valladares S, Abarca D, Díaz-Sala C: Characterization and expression of a Pinus radiata putative ortholog to the Arabidopsis SHORT-ROOT gene. Tree Physiol 2008, 28:1629-1639.

8. Abarca D, Díaz-Sala C: Adventitious root formation in conifers. In Adventitious Root Formation of Forest Trees and Horticultural Plants- From Genes to Applications. Kerala, India: Research Signpost;Niemi K \& Scagel C 2009:227-257.

9. Abarca D, Díaz-Sala C: Reprogramming adult cells during organ regeneration in forest species. Plant Signal Behav 2009, 4:8793-795.

10. Park YS: Implementation of conifer somatic embryogenesis in clonal forestry: technical requirements and deployment considerations. Ann For Sci 2002, 59:651-656.

11. Klimaszewska K, Trontin J-F, Becwar MR, Devillard C, Park Y-S, Lelu-Walter MA: Recent progress in somatic embryogenesis of four Pinus spp. Tree For Sci Biotech 2007, 1:11-25.

12. Bonga JM, Klimaszewska K, von Aderkas P: Recalcitrance in clonal propagation, in particular of conifers. Plant Cell Tissue Organ Cult 2010 100:241-254

doi:10.1186/1753-6561-5-S7-P136

Cite this article as: Hernández et al:: Expression pattern of the GRAS gene family during somatic embryogenesis in pine. BMC Proceedings 2011 5(Suppl 7):P136.

\section{Submit your next manuscript to BioMed Central and take full advantage of:}

- Convenient online submission

- Thorough peer review

- No space constraints or color figure charges

- Immediate publication on acceptance

- Inclusion in PubMed, CAS, Scopus and Google Scholar

- Research which is freely available for redistribution

Submit your manuscript at www.biomedcentral.com/submit 